\title{
Disulfide-bridging PEGylation during refolding for the more efficient production of modified proteins
}

\author{
Claire Ginn, ${ }^{1}$ Ji-won Choi ${ }^{2}$ and Steve Brocchini ${ }^{1 *}$ \\ ${ }^{1}$ UCL School of Pharmacy, 29-39 Brunswick Square, London, WC1N 1AX \\ ${ }^{2}$ PolyTherics Ltd, Babraham Research Campus, Babraham, Cambridge CB22 3AT
}

*Corresponding Author: Professor Steve Brocchini (steve.brocchini@ucl.ac.uk)

UCL School of Pharmacy, 29-39 Brunswick Square, London, WC1N 1AX, UK.

Keywords: protein modification, process integration, disulfide-bridging PEGylation, refolding PEGylation

\begin{abstract}
Abbreviations: DDM, $n$-dodecyl $\beta$-D-maltoside; DTT, dithiothreitol; EDTA, ethylenediamine tetraacedic acid; EMCV, encephalomyocarditis virus; FBS, fetal bovine serum; GuHCl, guanidine hydrochloride; IBs, inclusion bodies; IFN- $\beta 1 \mathrm{~b}$, interferon-beta $1 \mathrm{~b}$; MALDI-TOF mass spectrometry, matrix assisted laser desorption/ionization- time of flight mass spectrometry; PCR, polymerase chain reaction; PEG, poly(ethylene glycol); RNase T1, ribonuclease T1; TCEP, tris(2-carboxyethyl)phosphine
\end{abstract}




\begin{abstract}
Proteins that are modified by chemical conjugation require at least two separate purification processes. First the bulk protein is purified, and then after chemical conjugation, a second purification process is required to obtain the modified protein. In an effort to develop new enabling technologies to integrate bioprocessing and protein modification, we describe the use of disulfide-bridging conjugation to conduct PEGylation during protein refolding. Preliminary experiments using a PEG-mono-sulfone reagent with partially unfolded leptin and unfolded RNAse $\mathrm{T} 1$ indicated that the cysteine thiols underwent disulfide-bridging conjugation to give the PEGylated proteins. Interferon- $\beta 1 \mathrm{~b}$ (IFN- $\beta 1 \mathrm{~b}$ ) was then expressed in E.coli as inclusion bodies and found to undergo disulfide bridging-conjugation during refolding. The PEG-IFN$\beta 1 \mathrm{~b}$ was isolated by ion-exchange chromatography and displayed in vitro biological activity. In the absence of the PEGylation reagent, IFN- $\beta 1 b$ refolding was less efficient and yielded protein aggregates. No PEGylation was observed if the cysteines on IFN- $\beta 1 \mathrm{~b}$ were first modified with iodoacetamide prior to refolding. Our results demonstrate that the simultaneous refolding and disulfide bridging PEGylation of proteins could be a useful strategy in the development of affordable modified protein therapeutics.
\end{abstract}




\section{Introduction}

Proteins that are modified by chemical conjugation generally require at least two separate purification processes. The bulk protein must first be purified, and then after chemical conjugation, a second purification process is required to obtain the modified protein [1]. There are many protein modifications that are conducted for a wide range of applications in industry, and consumer and healthcare [2-4]. A clinically proven protein modification used on a wide range of proteins is the covalent conjugation of poly(ethylene glycol) (PEG) to a protein. Protein PEGylation increases the circulation time of the modified protein and has improved the clinical efficacy for several proteins [5-7] while also decreasing the propensity for protein aggregation [8-12]. Therapeutic proteins must meet stringent specifications for purity and their manufacture is often by batch processes that are complex and expensive. To simplify manufacturing, there is much ongoing effort to develop new enabling technologies to create continuous bioprocessing strategies, especially for downstream processing [13-16], e.g. the integration of protein refolding from inclusion bodies (IBs) and purification steps [17].

There are many advantages to using E. coli for the production of proteins [18-24] (e.g. rapid growth and high yield), especially for non-glycosylated proteins (antibody fragments, some cytokines, novel protein scaffolds) which continue to be developed. Although not universally true [25], IBs can contain a high proportion of the target protein which is protected from proteolytic degradation [18, 26-27]. IBs can also be readily separated during early downstream processing. Unfortunately protein refolding from IBs often involves extensive optimisation and bioprocessing, but continuing improvements in IB solubilisation are resulting in better recoveries of the correctly folded protein [28]. Of the many additives that have been examined during protein folding from IBs, unconjugated PEG has also been used to suppress aggregation [29-32].

There is the possibility that covalently modifying a protein with PEG during refolding could be used to increase refolding recovery. If PEGylation during refolding can be achieved, then two separate purification processes for the starting protein and again for the PEGylated protein would not be necessary. The PEG modification step would be incorporated into the refolding process and less additives would be necessary for successful refolding to occur. Refolding of more hydrophobic proteins might be possible where the presence of the 
conjugated PEG would impart steric shielding effects to minimise protein-protein interactions leading to aggregation. The PEGylation reagent must undergo efficient conjugation at a specific amino acid residue on the target protein for PEGylation to be conducted prior to the bulk protein first being purified or during refolding,

We have developed hydrolytically stable, bis-alkylation PEGylation reagents $\underline{\mathbf{1}}$ and $\underline{\mathbf{3}}$ (Figure 1A) that undergo conjugation with two cysteine sulfur atoms, derived from a reduced disulfide bond, to give a three-carbon bridge linking the cysteine thiols. This type of PEGylation is known as disulfide bridging PEGylation (Figure 1B) [33-35]. PEG-bis-sulfone $\underline{1}$ first undergoes an elimination reaction in situ to generate the PEG-mono-sulfone $\mathbf{3}$ (Figure 1A) which then undergoes conjugation with the protein by a sequence of addition-elimination reactions. Such reactions are known to be able to give a thermodynamically stable product [36]. The PEG-mono-sulfone $\underline{\mathbf{3}}$ can be isolated and used directly. The reagent is much more selective for cysteine thiols than amines (e.g. N-terminus, residues of lysine, histidine, arginine) at $\mathrm{pH}$ values less than 8.0. Due to the reaction mechanism of the conjugation, PEGreagent $\underline{3}$ (Figure 1B) is able to produce the most stable product thermodynamically. Hence it was hoped the refolding process could be made more efficient by the presence of PEG and by the nature of the conjugation reaction.

During refolding, disulfide bonds are usually formed by two thiol-disulfide exchange reactions with a redox reagent or another protein [37-38]. Disulfide bond formation is thought to occur after conformational ordering and partial folding of the protein [37-42]. Disulfide bond formation is thermodynamically coupled to the conformational folding of the protein [37-42]. Known as oxidative refolding, optimisation is often empirical requiring the judicious use of redox buffers and quenching conditions of the redox couple. The use of PEG-monosulfone $\underline{\mathbf{3}}$ avoids the need for oxidative refolding. Although attempts to integrate PEG modification during refolding or after partial protein unfolding have been described [34, 4348], there remains a fundamental need to examine more efficient and site-specific PEGylation reagents that would assist in the protein folding process.

\section{FIGURE 1}

Intially refolding PEGylation studies were conducted using PEG-mono-sulfone $\underline{\mathbf{3}}$ with two model proteins, leptin and RNase T1 to evaluate the feasibility of our approach. We then describe PEGylation the during the refolding of interferon-beta $1 \mathrm{~b}$ (IFN- $\beta 1 \mathrm{~b}$ ) which is clinically registered to treat multiple sclerosis and considered a difficult protein to refold. The 
majority of the studies described here were conducted with PEG-mono-sulfone $\underline{\mathbf{3}}$ that was derived from a $20 \mathrm{kDa}$ PEG precursor (hence $\mathrm{PEG}_{20}-$ mono-sulfone $\underline{\boldsymbol{3}}$ ). IFN- $\beta 1 \mathrm{~b}$ is produced from E. coli, however it is well known to be a hydrophobic protein [49-51] that can be difficult to refold from IBs [52]. IFN- $\beta 1 \mathrm{~b}$ is a cytokine and is an example of an $\alpha$-helical barrel protein, of which several are used clinically [53]. Several cytokines are also PEGylated and some are used as first line treatments for disease (e.g. PEGylated IFN- $\alpha 2$ : Pegasys ${ }^{\text {TM }}$ and PegIntron ${ }^{\mathrm{TM}}$; and PEGylated GCSF: Neulasta ${ }^{\mathrm{TM}}$ and Lonquex $\left.{ }^{\mathrm{TM}}\right)$. PEGylated interferon-beta 1a (IFN- $\beta 1$ a), which is a glycosylated variant of IFN- $\beta$, was registered for clinical used in the USA in 2014 [53-55]. Preliminary refolding PEGylation experiments using the same $\mathrm{PEG}_{20^{-}}$ mono-sulfone $\underline{\mathbf{3}}$ (derived from $20 \mathrm{kDa} \mathrm{PEG}$ ) were conducted with partially unfolded leptin, another $\alpha$-helical barrel protein, and RNase T1. Although RNase T1 is not a cytokine, it has two disulfide bonds and is known to readily refold. Our hope was to determine whether any of the disulfide rebridged RNase could be obtained during folding.

\section{Materials \& Methods}

\subsection{Materials}

Recombinant lyophilized human leptin was purchased from Peprotech EC Ltd (cat no: 30027). RNase T1 (from aspergillus oryzae) was from Worthington Biochem (cat no: RT1S). SDS-PAGE analyses were conducted using an XCell Surelock Mini-Cell, precast 4-12\% NuPAGE Bis-Tris gels and MOPs and MES running buffer, with Novex Sharp protein markers (Invitrogen). Gels were stained using Coomassie-based InstantBlue stain (Expedeon) and Silver Express ${ }^{\circledR}$ (Invitrogen). HiTrap SP FF cation, Q FF anion exchange and PD10 protein desalting columns were supplied by GE Healthcare. PEG-bis-sulfone reagent $\underline{1}$ was supplied from PolyTherics Ltd and the reagent was treated $(15 \mathrm{mg}$ in $1 \mathrm{~mL}$ of $50 \mathrm{mM}$ sodium phosphate buffer, $\mathrm{pH}$ 7.4) at ambient temperature overnight to give the PEG-mono-sulfone $\underline{\mathbf{3}}$. MicroBCA assay and Ellman's reagent were obtained from Thermo Scientific. UV measurements were obtained with a Hitachi U-2800A dual beam spectrometer and a Wallac Victor $^{2} 1420$ plate reader. The A549 and Daudi cell lines, and encephalomyocarditis virus (EMCV) were obtained from the ATCC. Fetal bovine serum (FBS), RPMI 1640 media, Dulbecco's Modified Eagle Medium (DMEM), L-glutamine and penicillin/streptomycin were purchased from PAA laboratories. All other buffer components were purchased from Sigma Aldrich. 


\subsection{Methods}

\subsubsection{Refolding PEGylation of RNase T1}

RNase $\mathrm{T} 1(0.45 \mathrm{mg} / \mathrm{mL}$ in $2.8 \mathrm{M}$ ammonium sulfate, Worthington) was denatured by buffer exchange using a PD10 column into denaturing buffer $(50 \mathrm{mM}$ sodium phosphate $6 \mathrm{M}$ guanidine hydrochloride $(\mathrm{GuHCl} ; \mathrm{pH} 7.8)$ and then DTT was added to give a concentration of $50 \mathrm{mM}$. After incubation at ambient temperature for $30 \mathrm{~min}$, the DTT was removed using a PD10 column into $100 \mathrm{mM}$ Tris-HCl, $\mathrm{pH} 8.0$ containing $1.9 \mathrm{M} \mathrm{GuHCl}$ and $0.4 \mathrm{M}$ sodium chloride $(\mathrm{NaCl})$. After a $45 \mathrm{~min}$ incubation at $4{ }^{\circ} \mathrm{C}, \mathrm{PEG}_{20}$-mono-sulfone $\underline{\mathbf{3}}$ ( $54.0 \mu \mathrm{L}$ of a 15.0 $\mathrm{mg} / \mathrm{mL}$ solution; 1.0 equiv.) was added to this refolding protein solution and further incubated for $1 \mathrm{~h} 45 \mathrm{~min}$ at $4{ }^{\circ} \mathrm{C}$. The reaction mixture was buffer exchanged into $20 \mathrm{mM}$ Tris-HCl, $\mathrm{pH}$ 8.0 and then loaded at a flow rate of $1 \mathrm{~mL} / \mathrm{min}$ onto a Q FF column pre-equilibrated with the same buffer. The unconjugated PEG reagent eluted from the column first and then the PEGylated RNase was obtained using a multiple-step gradient from 0.2-0.4 M NaCl using $0.02 \mathrm{M}$ elution increments of $5 \mathrm{~mL}$ collecting $1 \mathrm{~mL}$ fractions.

\subsubsection{Activity assay for PEGylated RNase T1}

Substrate solution was prepared by dissolving $10 \mathrm{mg}$ of yeast RNA in $1 \mathrm{~mL}$ of Tris buffer (50 mM Tris-HCl, 2 mM EDTA, $\mathrm{pH}$ 7.5) [56]. Methylene blue buffer was prepared in an amber bottle by dissolving $1 \mathrm{mg}$ of methylene blue hydrate in $100 \mathrm{~mL}$ of prepared Tris buffer. The absorbance of the prepared buffer solution at $688 \mathrm{~nm}$ was then checked and adjusted to $0.5 \pm$ 0.01 by the addition of further buffer. For the assay, $920 \mu \mathrm{L}$ of methylene blue buffer was added to $80 \mu \mathrm{L}$ of RNA substrate solution in $1.5 \mathrm{~mL}$ cuvettes. Cuvettes were then preincubated in the dark for $10 \mathrm{~min}$ at $25^{\circ} \mathrm{C}$ to enable RNA/methylene blue complex formation. The reaction was then started by the addition of $10 \mu \mathrm{L}$ volumes of different concentrations of RNase T1 $(10,5,2.5$ and $1.25 \mu \mathrm{g})$ and the PEGylated conjugate $(10 \mu \mathrm{g})$. No RNase T1 was added to control cuvette. The change in absorbance at $688 \mathrm{~nm}$ was measured over $20 \mathrm{~min}$ by spectrophotometer.

\subsubsection{PEGylation and partial refolding of leptin}

Lyophilised leptin (Peprotech EC) was reconstituted in the reduction buffer (50 mM sodium phosphate, $20 \mathrm{mM}$ EDTA, $2 \mathrm{M}$ arginine mono-hydrochloride, $\mathrm{pH}$ 7.4). To the resulting solution was added $3.1 \mathrm{mg}$ of dithiothreitol (DTT) to achieve a reductant concentration of 20 $\mathrm{mM}$ and incubated for $30 \mathrm{~min}$ at $4{ }^{\circ} \mathrm{C}$. The reduced protein was then buffer exchanged by 
means of a PD10 column into fresh reduction buffer to give a final volume of $2 \mathrm{~mL}$. The $\mathrm{PEG}_{20}$-mono-sulfone $\underline{\mathbf{3}}$ ( $5 \mathrm{mg} / \mathrm{mL}$ in $50 \mathrm{mM}$ sodium phosphate, $\mathrm{pH} 7.4 ; 1.5$ molar equiv.) was added to the reduced leptin and the solution was incubated overnight at $4{ }^{\circ} \mathrm{C}$. Conversion of native leptin to mono-PEG-leptin was determined by densitometric analysis of the resulting gel bands using ImageQuant software. Purification was conducted using a HiTrap SP FF column. Prior to purification, the reaction mixture was buffer exchanged into the loading buffer (20 mM sodium acetate, $\mathrm{pH} 4.0)$ and then loaded $(3.5 \mathrm{~mL})$ onto a HiTrap SP FF column $(1 \mathrm{~mL})$. Unreacted PEG was removed from the column by washing with 5 column volumes $(1 \mathrm{~mL}$ each) of the loading buffer. Separation of the PEG-leptin conjugate from the remaining reaction components was achieved using a linear gradient of $0-50 \%$ of $20 \mathrm{mM}$ sodium acetate, $\mathrm{pH} 4.0$ containing $1 \mathrm{M} \mathrm{NaCl}$ over $40 \mathrm{~min}$ at a flow rate of $1 \mathrm{~mL} / \mathrm{min}$. The identity of each of the peaks and the resulting fractions were characterised by SDS-PAGE.

\subsubsection{Expression and solubilisation of IFN- $\beta 1 b$ inclusion bodies}

The plasmid harbouring the sequence for human IFN- $\beta 1 \mathrm{~b}$ along with an eight-residue Nterminal histidine tag (Gene Oracle) was amplified by polymerase chain reaction (PCR) using the following primers; forward 5'-CACCATGCATCACCACCATCATCATCAC-3' and reverse 5'-TTATTAGTTACGAAGGTATCCTGTC-3'. The amplified gene was then ligated into the PET-101/D-TOPO vector (Invitrogen) and used to transform E. coli BL21 (DE3) cells. The presence of the inserted gene was confirmed by restriction enzyme digestion using $\mathrm{XbaI}$ and HindIII and by sequencing. A single E. coli colony containing the recombinant plasmid was selected and grown overnight in lysogeny broth (LB) at $37{ }^{\circ} \mathrm{C}$ shaking at 200 rpm for the inoculum of the large-scale fermentation. E. coli containing the recombinant plasmid were grown in terrific broth (TB) $(24 \mathrm{~g} / \mathrm{L}$ yeast extract, $12 \mathrm{~g} / \mathrm{L}$ tryptone, $4 \mathrm{~mL} / \mathrm{L}$ glycerol, $3.31 \mathrm{~g} / \mathrm{L} \mathrm{KH}_{2} \mathrm{PO}_{4}$ and $12.54 \mathrm{~g} / \mathrm{L} \mathrm{K}_{2} \mathrm{HPO}_{4}$ ) at $37{ }^{\circ} \mathrm{C}$ on a shaking incubator at 200 $\mathrm{rpm}$ in the presence of $100 \mu \mathrm{g} / \mathrm{mL}$ ampicillin until the $\mathrm{OD}$ at $600 \mathrm{~nm}$ reached 0.5 . Induction was then carried out using $1 \mathrm{mM}$ isopropyl- $\beta$-D-thiogalactopyranoside (IPTG). After $2.5 \mathrm{~h}$ of induction, the cells were harvested by centrifugation (Sorvall Legend RT+) at 2,500 $\mathrm{g}$ for 30 min at $4{ }^{\circ} \mathrm{C}$. Pelleted cells were resuspended in PBS containing $0.2 \mathrm{mg} / \mathrm{mL}$ lysozyme and $0.02 \mathrm{mg} / \mathrm{mL}$ DNase, incubated with shaking at ambient temperature for $2 \mathrm{~h}$, then lysed by sonication (QSonica Q500 with 1/2" diameter probe) for $2 \mathrm{~min}$ at $100 \%$ for 0.5 cycles. Sonication was then repeated twice. Soluble material was then isolated by centrifugation $\left(2,500 \mathrm{~g}, 30 \mathrm{~min}\right.$ at $\left.4{ }^{\circ} \mathrm{C}\right)$ and pellets were washed with PBS/1\% Triton-X100 $(10 \mathrm{~mL} / \mathrm{g}$ of 
pellet) and left shaking overnight at $4{ }^{\circ} \mathrm{C}$. Following another centrifugation step, the pellets were washed with PBS/1 mM TCEP (20 mL/g of pellet) and sonicated for $2 \mathrm{~min}$ at $100 \%$ for 0.5 cycles, and the pellet recovered through centrifugation. This was followed by another washing $(20 \mathrm{~mL} / \mathrm{g}$ of $50 \mathrm{mM}$ Tris, $\mathrm{pH} 8.0$ containing $150 \mathrm{mM} \mathrm{NaCl})$, sonication $(1 \mathrm{M}$ urea and $0.2 \%$ Triton-X100) and then centrifugation ( $5 \mathrm{~mL} / \mathrm{g}$ of $\mathrm{dH}_{2} \mathrm{O}$ containing $2 \mathrm{mM}$ EDTA). The washed inclusion bodies were then solubilised in $50 \mathrm{mM}$ Tris- $\mathrm{HCl}, \mathrm{pH} 8.0$ containing 6 $\mathrm{M} \mathrm{GuHCl}, 2 \mathrm{mM}$ EDTA and $20 \mathrm{mM}$ DTT at a protein concentration of $10 \mathrm{mg} / \mathrm{mL}$, heated to $55{ }^{\circ} \mathrm{C}$ for $30 \mathrm{~min}$, then allowed to cool overnight at ambient temperature. The solubilised inclusion bodies were then centrifuged $\left(21,000 \mathrm{~g}, 45 \mathrm{~min}\right.$ at $\left.4{ }^{\circ} \mathrm{C}\right)$ to separate the soluble protein from the aggregates.

\subsubsection{PEGylation of IFN- $\beta 1 b$ on refolding}

For PEGylation, the supernatant was buffer exchanged using a PD10 column into a refolding buffer $(50 \mathrm{mM}$ sodium phosphate, $\mathrm{pH} 7.8$ containing $20 \mathrm{mM}$ EDTA, $6 \mathrm{M} \mathrm{GuHCl}$ and $1 \mathrm{mg}$ $\mathrm{mL}$ of $n$-dodecyl $\beta$-D-maltoside (DDM)). This step also served to remove the excess DTT that was used to solubilise the IBs. The concentration of the target protein in the prepared IBs was estimated using a human serum IFN- $\beta 1$ b ELISA kit. The concentration of the solubilised IFN- $\beta 1 \mathrm{~b}$ inclusion bodies were then adjusted to $0.3 \mathrm{mg} / \mathrm{mL}$ by the addition of further denaturing buffer. Refolding was then carried out by a two-step dilution by the addition of the refolding buffer initially to $4 \mathrm{M} \mathrm{GuHCl}$, then to $2 \mathrm{M} \mathrm{GuHCl}$. Each dilution step was followed by an incubation at $4{ }^{\circ} \mathrm{C}$ for $4 \mathrm{~h}$. To the prepared IBs was added 1 molar equivalent of $20 \mathrm{kDa}$ PEG-bis-sulfone 1 ( $\mathrm{PEG}_{20}$-bis-sulfone 1), which had been pre-activated overnight at $37{ }^{\circ} \mathrm{C}$ in $50 \mathrm{mM}$ sodium phosphate, $\mathrm{pH} 7.8$ in order to generate the reactive mono-sulfone form of the reagent in situ (PEG-mono-sulfone $\mathbf{3}$ ). $\mathrm{PEG}_{20}-\mathrm{IFN}-\beta 1 \mathrm{~b}$ was then separated from other reaction components such as unreacted protein, unreacted PEG and multi-PEGylated species using ion exchange chromatography (IEC). The PEGylation reaction mixture was initially buffer exchange using a PD10 column into $50 \mathrm{mM}$ sodium phosphate, $\mathrm{pH} 6.0$ containing $0.1 \mathrm{mg} / \mathrm{mL}$ DDM. The buffer exchanged reaction mixture was then loaded onto the column (HiTrap SP FF) and the diPEG-IFN- $\beta 1 \mathrm{~b}$ conjugate eluted from the column using $0.2 \mathrm{M} \mathrm{NaCl}$ while the mono-PEG-IFN- $\beta 1 \mathrm{~b}$ conjugate was eluted using $0.26 \mathrm{M} \mathrm{NaCl}$ and any unreacted native IFN$\beta 1 \mathrm{~b}$ was eluted with $0.4 \mathrm{M} \mathrm{NaCl}$. Purity estimations were made by running each of the fractions on a $4-12 \%$ Bis-Tris SDS-PAGE gel and the concentration of the PEGylated conjugate was determined by UV and microBCA assay. 


\subsubsection{Western blot analysis}

Reaction mixtures were analysis by $4-12 \%$ Bis-Tris SDS-PAGE and transferred onto nitrocellulose membranes using a XCell II ${ }^{\mathrm{TM}}$ Blot Module CE Mark (Invitrogen) for $1 \mathrm{~h}$ at 30 $\mathrm{V}$. The membrane was then blocked for $1 \mathrm{~h}$ at ambient temperature using PBS supplemented with $0.1 \%$ Tween-20 (PBS/T) with 5\% w/v dried skimmed milk. Blots were incubated with rabbit anti-IFN- $\beta$ primary antibody (1/1000 dilution) for $1 \mathrm{~h}$ at ambient temperature and then with anti-rabbit alkaline phosphate (AP) conjugated secondary antibody (1/5000 dilution) (both from Abcam) for another $1 \mathrm{~h}$ at ambient temperature. The target protein was then detected using Sigma BCIP ${ }^{\circledR} /$ NBT tablets.

\subsubsection{In vitro bioactivity of PEGylated and refolded IFN- $\beta 1 b$}

The activity of the refolded and PEGylated was assessed by antiviral assay based on the ability of IFN- $\beta 1 \mathrm{~b}$ to protect human lung carcinoma (A549) cells from the cytopathic effects of the encephalomyocarditis virus (EMCV). The A549 cell line was maintained in DMEM media supplemented with 10\% fetal bovine serum (FBS), 50 units $/ \mathrm{mL}$ penicillin, 50 units $/ \mathrm{mL}$ of streptomycin and $2 \mathrm{mM} \mathrm{L}$-glutamine at $37{ }^{\circ} \mathrm{C}$ in a humidified atmosphere of $5 \% \mathrm{CO}_{2}$. For the purpose of the antiviral assay cells were resuspended at a concentration of $1.7 \times 10^{6}$ cells $/ \mathrm{mL}$ and $50 \mu \mathrm{L}$ of the cell suspension was seeded into the wells of a 96 -well flat bottom microtitre plate. Following overnight incubation at $37^{\circ} \mathrm{C}$ two-fold serial dilutions of each of the test samples were added to the wells in duplicate. The plates were then incubated at $37^{\circ} \mathrm{C}$ for $24 \mathrm{~h}$. The media was removed from the plates and $50 \mu \mathrm{L}$ of $1.6 \times 10^{5} \mathrm{PFU} / \mathrm{mL}$ solution of EMCV in DMEM/2\% FBS was added to each well. A positive control with cells and EMCV only and a negative control of just cells were also prepared on each plate. The following day cells in the positive control wells were visually inspected until $\sim 80 \%$ of the cells appeared dead. Wells were washed twice with $150 \mu \mathrm{L}$ sterile PBS and cell viability was then assessed by staining with $50 \mu \mathrm{L}$ of $4 \%$ formaldehyde $/ 0.1 \%$ methyl violet $2 \mathrm{~B}$ for $30 \mathrm{~min}$. Plates were washed twice with $150 \mu \mathrm{L}$ PBS and allowed to air dry before the remaining dye was solubilised in $50 \mu \mathrm{L}$ of $2 \%$ SDS by agitation and the absorbance at $570 \mathrm{~nm}$ was measured on a plate reader.

The antiproliferative activity of the PEGylated IFN- $\beta 1 \mathrm{~b}$ conjugate using a bioassay based on the ability of IFN- $\beta 1 \mathrm{~b}$ to inhibit the proliferation of the human Burkitt's lymphoma (Daudi) cell line. Daudi cells were maintained in RPMI media containing 10\% FBS and 50 units $/ \mathrm{mL}$ penicillin and 50 units $/ \mathrm{mL}$ of streptomycin in a humidified atmosphere of $5 \% \mathrm{CO}_{2}$ 
at $37^{\circ} \mathrm{C}$. For the assay, Daudi cells were seeded into 96-well U-bottom plates at a density of $10^{4}$ cells per well in $100 \mu \mathrm{L}$. To each well was added 3 -fold serial dilutions of each of the samples and standards in duplicate. Cells were then allowed to grow for $72 \mathrm{~h}$ at $37{ }^{\circ} \mathrm{C}$ before the addition of $20 \mathrm{uL}$ MTT to each well $(5 \mathrm{mg} / \mathrm{mL}$ in PBS sterile-filtered using a $0.22 \mu \mathrm{m}$ syringe filter). After a $3 \mathrm{~h}$ incubation at $37^{\circ} \mathrm{C}$, plates were centrifuged at $1,500 \mathrm{~g}$ for $10 \mathrm{~min}$ in order to pellet the dye. The media was aspirated from each well using a multi-channel pipette and the dye was solubilised in $100 \mu \mathrm{L}$ DMSO. Finally, the absorbance of each was read at $570 \mathrm{~nm}$ using a plate reader.

\subsubsection{MALDI- TOF mass spectrometry}

All samples were buffer exchanged into $10 \mathrm{mM}$ ammonium bicarbonate, $\mathrm{pH} 8.0$ using desalting spin columns prior to analysis. Mass analysis was carried out by matrix-assisted laser desorption time of flight mass spectrometry (MALDI-TOF) using an Applied Biosystems DE-PRO instrument with a nitrogen laser. The matrix was $20 \mathrm{mg} / \mathrm{mL}$ sinapinic acid in a 50:50 mixture of acetonitrile:water and 0.1\% trifluoroacetic acid (TFA). Sample and matrix were mixed at a ratio of $1: 1$ and $1 \mu \mathrm{L}$ spotted onto a 100 -well sample plate. Mass spectra were acquired in positive ion mode against an internal standard of bovine carbonic anhydrase. Low molecular mass species (600-2,500 Da) were observed using the highresolution reflectron mode (20 kV accelerating voltage, $350 \mathrm{~ns}$ extraction delay time) and high molecular mass species $(2-100 \mathrm{kDa})$ were observed using the low-resolution linear mode ( $25 \mathrm{kV}$ accelerating voltage, $750 \mathrm{~ns}$ extraction delay time).

\subsubsection{Tryptic digestion and MALDI-TOF mass spectrometry}

Sequence grade modified trypsin (Promega) was solubilised in $50 \mathrm{mM}$ acetic acid to a concentration of $0.2 \mathrm{mg} / \mathrm{mL}$. To samples of both the native protein and the mono-PEG-IFN$\beta 1 \mathrm{~b}$ conjugate were added a 1:20 ratio of trypsin to protein and incubated at $37^{\circ} \mathrm{C}$ for approximately 16 hours. Samples were then analysed by MALDI-TOF mass spectrometry according to method outlined above.

\subsubsection{Stability studies}

Aliquots of samples in $50 \mathrm{mM}$ sodium phosphate, $\mathrm{pH} 7.4$ were stored up to 4 weeks at $37{ }^{\circ} \mathrm{C}$. Sample stability was then assessed by SDS-PAGE analysis using both Coomassie InstantBlue and barium iodide staining. 


\section{Results}

\subsection{Refolding PEGylation of RNase T1.}

The two disulfide bonds of RNase T1 were reduced in denaturing conditions and the protein refolded by buffer exchange into $0.1 \mathrm{M}$ Tris- $\mathrm{HCl}, \mathrm{pH} 8.0$, containing $1.9 \mathrm{M} \mathrm{GuHCl}$ and $0.4 \mathrm{M}$ $\mathrm{NaCl}$. Using an enzymatic assay based upon the degradation of yeast RNA, the activity of RNAse T1 after refolding averaged $98.5 \%(n=3)$. RNase T1 was then refolded in the same solution during which 1 equivalent of $\mathrm{PEG}_{20}$-mono-sulfone $\underline{\mathbf{3}}$ (derived from $20 \mathrm{kDa}$ PEG) was added to the refolding solution 90 minutes after the start of the refolding process. Formation of the $\mathrm{PEG}_{20}$-RNase conjugate was observed (Figure 2, Lane 5). PEG migrates at approximately double its actual molecular weight compared to the protein molecular weight standards typically used in SDS-PAGE, i.e. PEG $_{20}$ band appears at approximately $40 \mathrm{kDa}$. This characteristic of PEG migration is maintained when PEG is conjugated to a protein. Since the molecular weight of RNase $\mathrm{T} 1$ is $11 \mathrm{kDa}$, the band at approximately $50 \mathrm{kDa}$ is consistent with that expected for $\mathrm{PEG}_{20}-\mathrm{RNase}$ conjugate (Figure 2, Lane 5). The gel was first stained with Coomassie InstantBlue stain to detect protein within the conjugate (Figure 2, Lane 4) and then barium iodide to detect PEG species. The band at $50 \mathrm{kDa}$ was stained for both protein and PEG (Figure 2, Lane 5). Trace di-PEG ${ }_{20}-\mathrm{RNase}$ and unconjugated RNase were also observed. Ion exchange chromatography was used to purify the $\mathrm{PEG}_{20}-\mathrm{RNase}$ conjugate (Figure 2, Lane 7) and the in vitro activity was determined to be $23 \%(n=3)$. Earlier addition of the $\mathrm{PEG}_{20}$-mono-sulfone $\underline{\mathbf{3}}$ to the refolding mixture resulted in the formation of more multi-PEGylated species (37\% conversion to the mono-PEG species at $30 \mathrm{~min}$ ). Later addition of $\mathrm{PEG}_{20}$-mono-sulfone $\underline{\mathbf{3}}$ resulted in reduced conversion to the $\mathrm{PEG}_{20}-\mathrm{RNase}$ conjugate $(54 \%$ at $60 \mathrm{~min}$ compared to $42 \%, 14 \%$ and $4 \%$ at 90,120 and $150 \mathrm{~min}$ respectively).

\section{FIGURE 2}

\subsection{Partial refolding PEGylation of leptin.}

Leptin is a $\alpha$-helical barrel protein with one disulfide bond located between a helix and a flexible loop. Preliminary experiments [35] showed that leptin could be PEGylated with $\mathrm{PEG}_{20}$-bis-sulfone $\underline{\mathbf{1}}$ in the presence of arginine, which was necessary to suppress leptin aggregation after disulfide reduction. Partial reduction of other cytokines (e.g. IFN- $\alpha 2)$ with the cysteines located in or near a helix does not result in the aggregation that is observed with 
leptin [34]. This is presumably due the location of the disulfide cysteines in or close to the helices and to the greater hydrophobic interactions between the helices to help maintain the tertiary structure after disulfide reduction. For this current study we wanted to explore the use of $\mathrm{PEG}_{20}$-mono-sulfone $\underline{\mathbf{3}}$ to determine whether this reagent would effectively undergo disulfide-bridging conjugation with partially unfolded leptin.

Disulfide reduced leptin was found to precipitate from solution in the absence of arginine with no formation of the $\mathrm{PEG}_{20}$-leptin conjugate (Figure $3 \mathrm{~A}$, lane 4). In the presence of $2 \mathrm{M}$ arginine hydrochloride and using 1.5 eq. of $\mathrm{PEG}_{20}-$ mono-sulfone $\underline{\mathbf{3}}$, the desired $\mathrm{PEG}_{20^{-}}$ leptin product was formed in good conversion ( $55 \%$ ) (Figure 3A, lanes 5-6). Trace amounts of higher molecular weight PEGylated products were also observed (Figure 3A, lanes 5-6) using these conditions. No conjugation was observed when the $\mathrm{PEG}_{20}$-mono-sulfone $\underline{\mathbf{3}}$ was added to leptin that had not been previously incubated with DTT (Figure 3A, lane 7). Ion exchange chromatography was used to purify $\mathrm{PEG}_{20}$-leptin (Figure $3 \mathrm{~A}$, lane 8 ) and the conjugate was stable with no evidence of de-PEGylation when stored in $50 \mathrm{mM}$ sodium phosphate, pH 7.4 for up to 4 weeks at $37{ }^{\circ} \mathrm{C}$ (Figure 3A, lane 9). No free thiols were detected by Ellman's assay following DTT treatment of the $\mathrm{PEG}_{20}$-leptin conjugate.

\section{FIGURE 3}

The MALDI-TOF (Figure 3B) of the $\mathrm{PEG}_{20}$-leptin conjugate (Figure 3A, lane 8) was $\sim 37 \mathrm{kDa}$ which is the expected mass for $\mathrm{PEG}_{20}$-leptin. Proteins that are conjugated to PEG do not display a single molecular weight in MALDI-TOF because the PEG precursors that are used to make PEGylation reagents are narrowly dispersed. These PEG precursors often have molecular weights that range from about $5 \%$ above and below the stated molecular weight.

The expected peptide fragments for the proteolytic digestion of leptin without prior treatment with DTT are shown in Figure 3C. Fragment 11 with the intact disulfide has a molecular weight of $5510.1 \mathrm{Da}$. Trypsin digestion of $\mathrm{PEG}_{20}$-leptin gave a single fragment with a conjugated PEG (Figure 3A, lane 10). No evidence was observed to suggest the existence of other lower molecular weight PEGylated fragments. The molecular weight of the $\mathrm{PEG}_{20}$-peptide fragment was approximately $25 \mathrm{kDa}$ (Figure 3D), which is consistent for the PEG fragment 12 (Figure 3C) derived from the $20 \mathrm{kDa}$ PEG-mono-sulfone $\underline{\mathbf{3}}$.

\subsection{Expression of IFN- $\beta 1 b$ and refolding PEGylation from inclusion bodies.}

Expression of (IFN- $\beta 1 \mathrm{~b}$ ) was induced for $2.5 \mathrm{~h}$ by the addition of $1 \mathrm{mM}$ IPTG to the shake flask culture. A band could be seen in the SDS-PAGE gel of both the crude extract and pellet 
fractions that corresponded to the predicted size of IFN- $\beta 1 \mathrm{~b}(21.4 \mathrm{kDa} ; 174 \mathrm{aa})$ (Figure 4A, lanes $1 \& 3$ ). No protein was visualised in the supernatant, indicating that the IFN- $\beta 1 \mathrm{~b}$ was expressed solely in the IB form (Figure 4A, lane 2). A $1 \mathrm{~L}$ fermentation yielded a total of 21.1 $\mathrm{g}$ of wet pellet, which after five washing steps gave approximately $2.5 \mathrm{~g}$ of IBs that were relatively pure in IFN- $\beta 1$ b (Figure 4A, lane 4). An anti-IFN- $\beta 1$ b western blot (Figure 4B, lane 6) was consistent for the presence of IFN- $\beta 1 \mathrm{~b}$ in the IBs.

\section{FIGURE 4}

Different refolding strategies in the presence of $\mathrm{PEG}_{20}$-mono-sulfone $\underline{\mathbf{3}}$ were examined. Dilution of IFN- $\beta 1 \mathrm{~b}$ in the presence of anti-aggregation additives (e.g. Tween-20, Triton X-100, Expedeon NV10 and $n$-dodecyl $\beta$-d-maltoside (DDM)) gave the most promising results. Other methods of refolding such as on-column and dialysis were also tested, but both gave a lower yield and more variable results compared to the dilution method. Refolding conditions were also optimised in terms of the reaction temperature, $\mathrm{pH}$, number of equivalents of the $\mathrm{PEG}_{20}$-mono-sulfone $\underline{\boldsymbol{3}}$, timing of $\mathrm{PEG}$ addition, number of dilution steps and refolding time. PEGylation and refolding were conducted in the presence of $\mathrm{PEG}_{20}-$ monosulfone $\underline{\mathbf{3}}$ ( 1 equiv.) and DDM $(1 \mathrm{mg} / \mathrm{mL})$ to give a good conversion of $\mathrm{PEG}_{20}$-IFN- $\beta 1 \mathrm{~b}$ with little observable unreacted IFN- $\beta 1$ b (Figure 4B, lanes 3-4) or multi-PEGylated protein species. Of the different additives that were examined to prevent protein aggregation, DDM was found to give a higher PEGylation conversion. This additive has been reported as being an effective aggregation suppressant for IFN- $\beta 1 \mathrm{~b}$ [57]. The $6 \mathrm{M} \mathrm{GuHCl}$ that was present did not appear to hinder the PEGylation reaction. Reactions were also conducted using $\mathrm{PEG}_{20^{-}}$ bis-sulfone 1 and the formation of PEG $_{20}$-IFN- $\beta 1$ b was also observed.

Anti-IFN- $\beta 1$ b western blot (Figure 4B, lane 7) was consistent with the formation of $\mathrm{PEG}_{20}$-IFN- $\beta 1$ b. Ion exchange chromatography was effective to purify the PEGylated IFN$\beta 1 \mathrm{~b}$ species from unconjugated PEG reagent and other cellular proteins (Figure 4B, lane 8). The total yield of $\mathrm{PEG}_{20}$-IFN- $\beta 1 \mathrm{~b}(600 \mu \mathrm{g}$ in IFN- $\beta 1 \mathrm{~b})$ following this single step of purification was $\sim 12 \%$ as determined by UV and microBCA protein assay. This yield is considered to be very good when compared to the process flow of conventional purification of the bulk protein, modification and then purification of the modified protein.

No non-specific conjugation was observed in the presence of $\mathrm{PEG}_{20}$-mono-sulfone $\underline{\mathbf{3}}$ when iodoacetamide had first been used to block the cysteine residues (Figure 4B, lane 5). When no PEG reagent was added to the refolding reaction, no refolded protein could be 
recovered. It was also discovered that the timing for the addition of the $\mathrm{PEG}_{20}$-mono-sulfone $\underline{\mathbf{3}}$ reagent is important to maximise the yield of $\mathrm{PEG}_{20}$-IFN- $\beta 1 \mathrm{~b}$ during refolding. Addition of PEG-mono-sulfone $\underline{\mathbf{3}}$ at $4 \mathrm{~h}$ appeared to be the optimal timepoint to obtain the mono- $\mathrm{PEG}_{20^{-}}$ IFN- $\beta 1 \mathrm{~b}$ conjugate. Early addition of the PEG-mono-sulfone $\underline{\mathbf{3}}$ ( 0 to $3 \mathrm{~h}$ ) to the refolding solution tended to result in the formation of a di-PEG 20 -IFN- $\beta 1 \mathrm{~b}$ conjugate, which was thought to be the unbridged conjugate with one PEG conjugated to each cysteine thiol. Later addition of the reagent (after $5 \mathrm{~h}$ up to $7 \mathrm{~h}$ ) failed to yield any PEGylated product.

Use of an equivalent mass of PEG 400 (50 protein equivalents) in an effort to refold IFN- $\beta 1 \mathrm{~b}$ in the absence of the $\mathrm{PEG}_{20}$-mono-sulfone $\underline{\mathbf{3}}$ did not give refolded IFN- $\beta 1 \mathrm{~b}$. Although the majority of the work in this study was done with the $20 \mathrm{kDa}$ PEG-mono-sulfone $\underline{\mathbf{3}}$, both $10 \mathrm{kDa}$ and $30 \mathrm{kDa}$ PEG-mono-sulfones $\underline{\mathbf{3}}$ also resulted in the formation of the corresponding PEG-IFN- $\beta 1 \mathrm{~b}$ conjugate during refolding of IFN- $\beta 1 b$.

The purified $\mathrm{PEG}_{20}$-IFN- $\beta 1 \mathrm{~b}$ conjugate was incubated for up to 4 weeks at $37{ }^{\circ} \mathrm{C}$ in

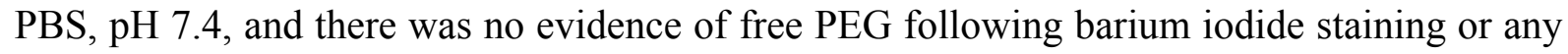
free IFN- $\beta 1$ b by SDS-PAGE (Figure 4B, Lane 8). No de-PEGylation was observed when the $\mathrm{PEG}_{20}$-IFN- $\beta 1 \mathrm{~b}$ conjugate was incubated in the presence of $10 \mathrm{mM}$ DTT for $15 \mathrm{~min}$ at ambient temperature. No free protein thiol was observed by Ellman's assay of the $\mathrm{PEG}_{20}$-IFN$\beta 1 \mathrm{~b}$ conjugate following DTT treatment.

The mass of the PEG $_{20}$-IFN- $\beta 1 \mathrm{~b}$ conjugate as determined by MALDI-TOF analysis was $41.2 \mathrm{kDa}$, an increase of $\sim 20 \mathrm{kDa}$ over the expected mass of the native protein $(21.4 \mathrm{kDa})$ (Figure 4C). The purified $\mathrm{PEG}_{20}$-IFN- $\beta 1 \mathrm{~b}$ conjugate was subjected to tryptic digestion to give a band for a fragment at approximately $40-45 \mathrm{kDa}$ that could be detected by barium iodide staining. (Figure 4B, Lane 10). Mass spectral analysis of the digestion mixture gave one broad signal at $21.2 \mathrm{kDa}$, which was consistent with fragment 20 (Figure 4D-E).

The activity of the $\mathrm{PEG}_{20}$-IFN- $\beta 1 \mathrm{~b}$ conjugate was evaluated using an antiviral assay based on the ability of IFN- $\beta 1 \mathrm{~b}$ to protect A549 cells from the effects of the encephalomyocarditis virus (EMCV) (Figure 5A). The $\mathrm{PEG}_{20}-\mathrm{IFN}-\beta 1 \mathrm{~b}$ conjugate was found to have an $\mathrm{ED}_{50}$ value of $389 \pm 32 \mathrm{pg} / \mathrm{mL}$ while the unmodified IFN- $\beta 1 \mathrm{~b}$ (NIBSC standard) had an $\mathrm{ED}_{50}$ of $2 \pm 0.1 \mathrm{IU} / \mathrm{mL}(n=4)$. A Daudi-based antiproliferative assay showed that the $\mathrm{PEG}_{20}$-IFN- $\beta 1 \mathrm{~b}$ conjugate (Figure $5 \mathrm{~B}$ ) displayed an $\mathrm{ED}_{50}$ value of $2688 \pm 301 \mathrm{pg} / \mathrm{mL}$ and the unmodified IFN- $\beta 1 \mathrm{~b}$ (NIBSC standard) displayed an $\mathrm{ED}_{50}$ value of $292 \pm 30 \mathrm{IU} / \mathrm{mL}(n=4)$.

\section{FIGURE 5}




\section{Discussion}

\subsection{Refolding driven by disulfide bridging conjugation}

Therapeutic proteins often have an accessible disulfide bond. Disulfides [40, 58], especially accessible disulfides [59], can act to increase the stability of the folded protein. The reaction mechanism for conjugation (Figure 1B) via an addition-elimination pathway provides the means to produce the thermodynamically most stable product [36]. This results in the conjugation of PEG via formation of a three-carbon bridge between the two cysteine thiols derived from a native disulfide [33-35]. The thermodynamic nature of the disulfide rebridging reaction is potentially valuable to help drive refolding without the need for redox couples during the refolding process while also simultaneously modifying the protein. Introduction of the PEG-mono-sulfone $\underline{\mathbf{3}}$ to the refolding solutions of RNase and IFN- $\beta 1 \mathrm{~b}$ was conducted when these proteins were partially refolded. Although many competing reactions remain possible, our observations indicate that the disulfide bridging PEGylation was able to occur as the protein completed its refolding.

We have also shown previously with several examples that disulfide bridging conjugation yields biologically active protein and that the thiol ether bonds in the conjugate are more stable than the original disulfide [33-35, 60-62]. Secreted proteins that are prepared from different sources are also purified before chemical modification. We anticipate our reagents would also be useful to modify secreted proteins early in their initial purification process in an analogous way to the modification of proteins during refolding from inclusion bodies.

Other methods of conjugation generally, and PEGylation specifically, do not target the two cysteine thiols of a native disulfide bond. These other conjugation methods are not involved in the aspect of protein folding that is related to the formation of covalent bonds between amino acid residues. In the case of difficult-to-fold proteins such as IFN- $\beta 1 b$, we wanted to show that the concept of disulfide bridging conjugation could also be used to aid the folding process. The presence of PEG on the conjugation reagent would also be advantageous to drive refolding since it is known that PEG additives can be used during refolding to suppress aggregation [29-32] and these favourable effects may be enhanced once PEG is site-specifically conjugated to the protein.

\subsection{Reagent stability in refolding conditions}


Dilution-based refolding was used in our studies because it is a simple and widely used method for small-scale refolding studies and has been scaled for use in protein manufacture. Although we recognise that refolding processes vary widely with each protein, our intent was to establish if PEGylation could be accomplished during refolding without substantially modifying what would be considered to be typical refolding conditions. Therefore, denaturant $(6 \mathrm{M} \mathrm{GuHCl})$ was used in our refolding experiments in the presence of only a small stoichiometric excess of the PEGylation reagent $\underline{\mathbf{1}}$ or $\underline{\mathbf{3}}$ (typically 1-2 equivalents). In spite of the high levels of denaturant present in the refolding buffer, the hydrolytic stability and thiol selectivity of reagents $\underline{\mathbf{1}}$ and $\underline{\mathbf{3}}$ are important characteristics to allow refolding PEGylation to be possible. The use of a slight stoichiometric excess of the reagent is also an important criterion to consider the potential scalability of our strategy. Results also indicated that the efficiency of PEGylation was improved when the refolding conjugation reactions were conducted in the presence of an aggregation suppressant. While the refolding conjugation conditions can be further optimised, it was gratifying that (i) the reagent was not consumed in these conditions, (ii) that PEGylation was observed and (iii) the PEGylated protein could be purified, isolated and characterised.

\subsection{Reagent thiol selectivity maintained in refolding conditions}

Thiol selectivity for reagent $\underline{\mathbf{1}}$ (and thus reagent $\underline{\mathbf{3}}$ ) is well established [33-35, 60, 62-63]. Characterisation of the refolding PEGylation of leptin with reagent $\underline{\mathbf{3}}$ is consistent with PEGylation on the leptin cysteine thiols (Figure 3). When the expressed IFN- $\beta 1 \mathrm{~b}$ was pretreated with iodoacetamide to cap the cysteine thiols, no PEGylation was observed. RNase T1 is a protein with two disulfide bonds and we found that it was possible to tailor the reactions to favour the PEGylation of only one disulfide bond by adding the PEG later in the refolding process when the disulfide formation had already started. By fully unfolding the protein there is potential for both disulfide scrambling as well as the generation of multi-PEGylated species especially in the case of proteins containing multiple disulfide bonds. The use of small excesses of PEG such as those utilised here would also decrease the potential for any intermolecular crosslinking reactions that could occur between proteins and instead favor the formation of the proteins disulfide bridge. Typically PEGylation with reagent $\underline{\mathbf{1}}$ is conducted on a fully folded protein after reduction of the accessible disulfide bond. Under these conditions the cysteine thiols remain spatially close. It is remarkable that a fully unfolded protein with more than one reduced disulfide bond can undergo disulfide bridging 
PEGylation. Using this method the desired conjugate could be isolated from the reaction mixture with good purity using only a single purification step.

\subsection{Maintenance of biological activity}

Some loss of biological activity is expected for PEGylation as a result of PEG shielding effects [7], which causes a decrease in the rate of association during binding to the target ligand or receptor $[60,64]$. For many proteins the existence of biological activity is a good indication of correct folding. Where the formation of the protein's disulfide bond is intrinsic to the biological activity, as in the case of RNase T1 and IFN- $\beta 1 b$, this can be used to further corroborate that PEG conjugation by disulfide rebridging has occurred. However, since PEGylation was conducted during protein folding, it is possible that some misfolded modified protein was present.

\subsection{Conclusion}

In conclusion, there is a continued need to simplify the processes used to obtain protein therapeutics. The PEG-mono-sulfone $\underline{\mathbf{3}}$ can be used during protein refolding to undergo disulfide rebridging conjugation. Many protein therapeutics require PEGylation, or other modification, to improve clinical efficacy. Conducting PEG modification with site specific reagents that can be used before the protein is purified while also driving refolding has the potential to be used to develop continuous, more efficient and cost-effective protein manufacturing processes. The refolded PEGylated proteins described in this study could be purified by ion exchange chromatography and retained biological activity. While refolding is very protein specific, the disulfide rebridging approach has the potential to be further developed for disulfide-containing therapeutic proteins.

Acknowledgements. $\mathrm{CG}$ is grateful to the BBSRC and PolyTherics Ltd for funding her PhD. SB is grateful for funding for funding from the National Institute of Health Research (NIHR) Biomedical Research Centre at Moorfields Eye Hospital NHS Foundation Trust and UCL Institute of Ophthalmology, Moorfields Special Trustees, the Helen Hamlyn Trust (in memory of Paul Hamlyn), Medical Research Council, Fight for Sight and Freemasons Grand Charity. SB is also grateful for funding from the UK Engineering \& Physical Sciences Research Council (EPSRC) for the EPSRC Centre for Innovative Manufacturing in Emergent Macromolecular Therapies. Financial support from the consortium of industrial and governmental users for the EPSRC Centre is also acknowledged. 
Conflict of interest statement. $\mathrm{JWC}$ is an employee at PolyTherics (now part of Abzena plc). SB was a co-founder of PolyTherics, but has remained a full-time employee of the UCL School of Pharmacy since the company was found. SB remains a consultant to PolyTherics. 


\section{Figure legends}

Figure 1. (A) The $\mathrm{PEG}_{20}$-bis-sulfone $\underline{\mathbf{1}}\left(\mathrm{R}^{1}=\right.$ aryl and $\mathrm{R}^{2}=$ tolyl) can undergo cysteine thiol specific conjugation at both of the $\beta$ carbons. The conjugation sequence starts after elimination of toluene sulfinic acid anion $\underline{\mathbf{2}}$ to give the $\mathrm{PEG}_{20}-$ mono-sulfone $\underline{\mathbf{3}}$ which has an $\alpha, \beta$-double bond to a carbonyl. (B) Mechanistically, bis-alkylation occurs by a sequence of addition-elimination steps thought to be thermodynamically driven. Elimination of a second equivalent of sulfinic anion 2 (i.e. $\mathrm{R}^{2} \mathrm{SO}_{2}{ }^{-}$) is thought to occur after the first conjugation reaction and this generates a new $\alpha, \beta$-double bond for the second conjugation to occur with a second cysteine sulfur atom resulting in disulfide bridged PEGylation.

Figure 2. SDS-PAGE gel (Novex 4-12\% Bis-Tris) showing the refolding PEGylation reaction between RNase $\mathrm{T} 1$ and $\mathrm{PEG}_{20}$-mono-sulfone $\underline{\mathbf{3}}$. The molecular weight of the PEG in the reagent was $20 \mathrm{kDa}$. SDS-PAGE migration of PEG is approximately double its actual molecular weight compared to protein molecular weight standard of equivalent size. The gel was stained with Coomassie InstantBlue stain to detect protein and then barium iodide $\left(^{*}\right)$ to detect PEG species. Lane $M$, molecular weight standards; lane 1, native RNase T1; lane 2, reduced and denatured $\mathrm{RNase} \mathrm{T} 1$; lane $3, \mathrm{PEG}_{20}-$ mono-sulfone $\underline{\mathbf{3}}$; lane 4 , reduced and denatured RNase $\mathrm{T} 1$ refolded in the presence of $\mathrm{PEG}_{20}$-mono-sulfone $\underline{\mathbf{3}}$ (1 equiv.); lane 5, sample from lane 4 that was stained with barium iodide after Commassie blue stain; lane 6, control reaction with non-reduced RNase $\mathrm{T} 1$ in $6 \mathrm{M} \mathrm{GuHCl}+1$ equiv. of $\mathrm{PEG}_{20}$-monosulfone $\underline{3}$; lane 7 , IEC purified $\mathrm{PEG}_{20}-\mathrm{RNase} \mathrm{T} 1$.

Figure 3. (A) SDS-PAGE gel (Novex 12\% Bis-Tris) of the reaction between leptin and $\mathrm{PEG}_{20}$-mono-sulfone $\underline{\mathbf{3}}$ (derived from $20 \mathrm{kDa}$ PEG) stained with Coomassie InstantBlue and silver stain $(\bullet)$ to detect protein and then barium iodide $(*)$ to detect PEG species. Lane $M$, molecular weight standards; lane 1, native leptin; lane 2, reduced leptin; lane 3, $\mathrm{PEG}_{20}$-monosulfone $\mathbf{3}$; lane 4, PEGylation reaction mixture: reduced leptin + PEG20-mono-sulfone $\underline{\mathbf{3}}$ (1.5 equiv.) in the absence of arginine; lanes 5-6, PEGylation reaction mixture: reduced leptin + $\mathrm{PEG}_{20}$-mono-sulfone 3 (1.5 equiv.) in the presence of $2 \mathrm{M}$ arginine stained with Coomassie blue and barium iodide respectively; lane 7, control reaction comprised of non-reduced Leptin $+\mathrm{PEG}_{20}$-mono-sulfone $\mathbf{3}$ (1.5 equiv.); lane 8, IEC purified $\mathrm{PEG}_{20}$-leptin; lane 9, $\mathrm{PEG}_{20}$-leptin after incubation at $4{ }^{\circ} \mathrm{C}$ for 28 days; lane 10, $\mathrm{PEG}_{20}$-leptin after $16 \mathrm{~h}$ incubation with 1:20 ratio of trypsin to protein. (B) MALDI-TOF mass spectrum of the purified $\mathrm{PEG}_{20}$-leptin conjugate. (C) Table of possible fragments generated after tryptic digestion of $\mathrm{PEG}_{20}$-leptin. (D) Low-resolution linear mode MALDI-TOF spectrum of digested $\mathrm{PEG}_{20}$-leptin showing the $\mathrm{PEG}_{20}$-peptide fragment at approximately 25,042 Da which is consistent with fragment 12 .

Figure 4. (A) SDS-PAGE (Novex 4-12\% Bis-Tris) analysis of the IFN- $\beta 1 \mathrm{~b}$ expression fractions. Lane $M$, molecular weight standards; lane 1, crude extract after induction; lane 2, supernatant after induction; lane 3, pellet after induction; lane 4, washed pellet. (B) SDSPAGE gel (Novex 4-12\% Bis-Tris) showing the results of the refolding PEGylation reactions. Staining accomplished with Coomassie InstantBlue and silver stain $(\bullet)$ to detect protein and then barium iodide (*) to detect PEG species. Lane $M$, molecular weight standards; lane 1, solubilised IFN- $\beta 1 \mathrm{~b}$ inclusion bodies; lane $2, \mathrm{PEG}_{20}$-mono-sulfone $\underline{\mathbf{3}}$; lane 3 , dilution refolding IFN- $\beta 1 \mathrm{~b}$ in the presence of $\mathrm{PEG}_{20}$-mono-sulfone $\mathbf{3}$ (1 equiv.); lane 4 , sample from lane 3 that was stained with barium iodide after Commassie blue stain; lane 5, pre-treatment of IFN- $\beta 1 \mathrm{~b}$ with iodoacetamide ( 2 equiv.) followed by dilution refolding of IFN- $\beta 1 \mathrm{~b}$ in the 
presence of $\mathrm{PEG}_{20}$-mono-sulfone $\underline{\mathbf{3}}$ (1 equiv.); lane 6 , anti-IFN- $\beta 1 \mathrm{~b}$ western blot of IFN- $\beta 1 \mathrm{~b}$ inclusion bodies; lane 7 , anti-IFN- $\beta 1 \mathrm{~b}$ western blot of the refolding mixture IFN- $\beta 1 \mathrm{~b}$ in the presence of $\mathrm{PEG}_{20}$-mono-sulfone $\underline{\mathbf{3}}$ (1 equiv.); lane 8, IEC purified $\mathrm{PEG}_{20}$-IFN- $\beta$; lane 9, $\mathrm{PEG}_{20}$-IFN- $\beta 1 \mathrm{~b}$ after incubation at $37^{\circ} \mathrm{C}$ for 28 days in $50 \mathrm{mM}$ sodium phosphate, $\mathrm{pH} 7.4$ at $1 \mathrm{mg} / \mathrm{mL}$; lane $10, \mathrm{PEG}_{20}$-IFN- $\beta 1 \mathrm{~b}$ after $16 \mathrm{~h}$ incubation at $37{ }^{\circ} \mathrm{C}$ with a $1: 20$ ratio of trypsin to protein. (C) MALDI-TOF mass spectrum of the purified $\mathrm{PEG}_{20}$-IFN- $\beta 1 \mathrm{~b}$ conjugate. (D) Table of possible fragments generated after tryptic digestion of $\mathrm{PEG}_{20}$-IFN- $\beta$. (E) Lowresolution linear mode MALDI-TOF spectrum of digested refolded PEG $_{20}$-IFN- $\beta 1 \mathrm{~b}$ showing the $\mathrm{PEG}_{20}$-peptide fragment that is consistent with fragment 20 . The peak at $23.3 \mathrm{kDa}$ can be attributed to a small amount of residual trypsin.

Figure 5. In vitro bioactivity of NIBSC IFN- $\beta 1 \mathrm{~b}(\bullet)$ and the $20 \mathrm{kDa}$ refolded and PEGylated IFN- $\beta 1$ b conjugate $(\mathbf{\Lambda})$ as assessed using by $(\mathbf{A})$ antiviral and (B) antiproliferative assays. 
Figure 1

A
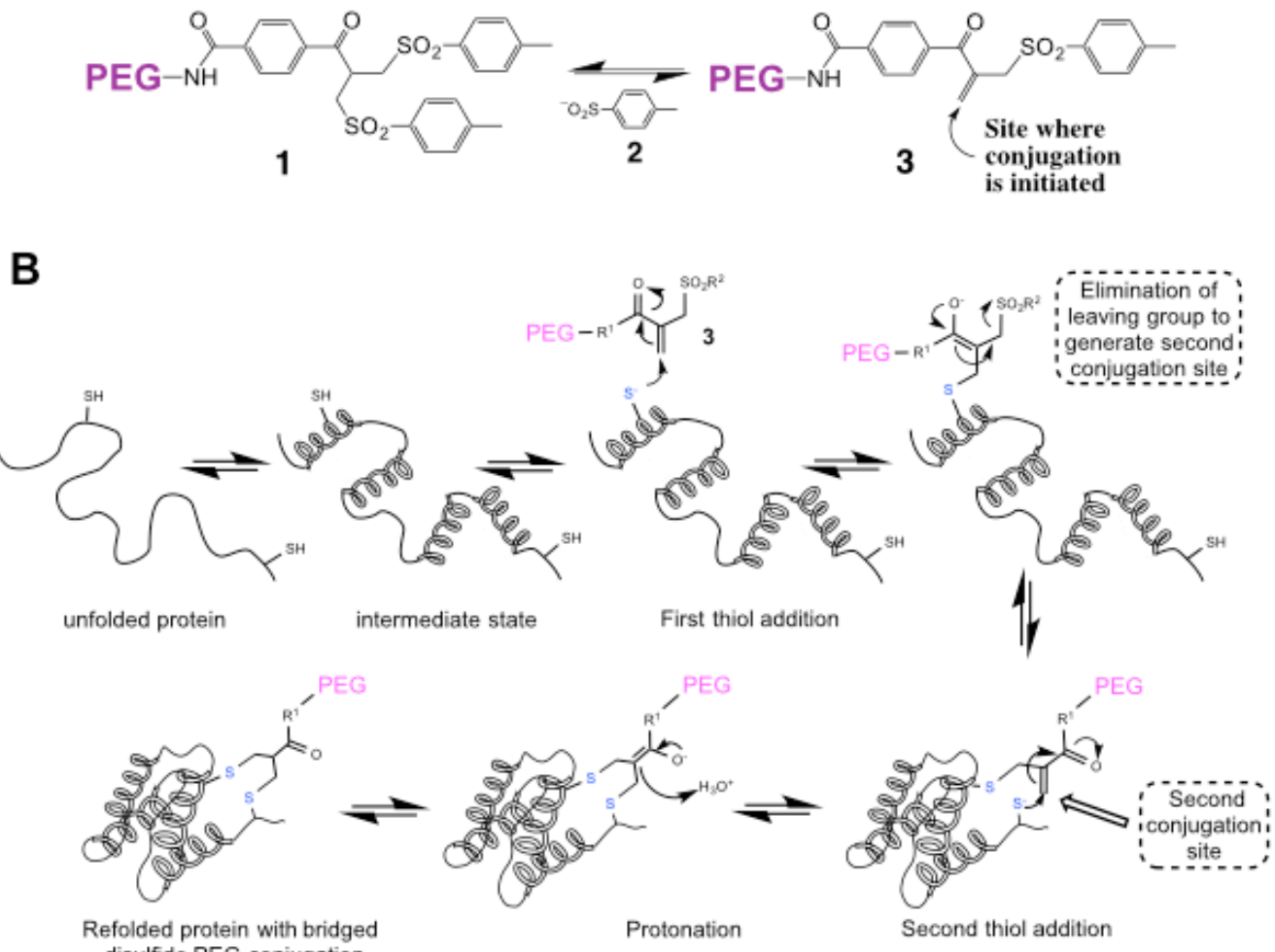
Figure 2

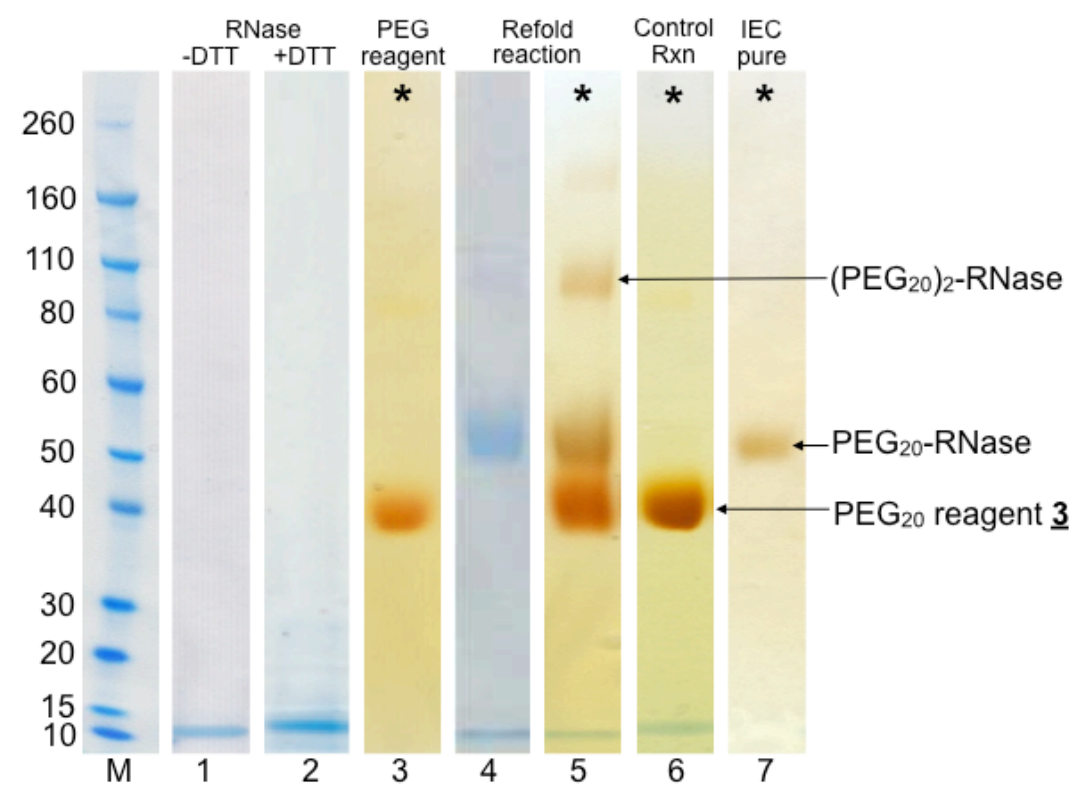


Figure 3
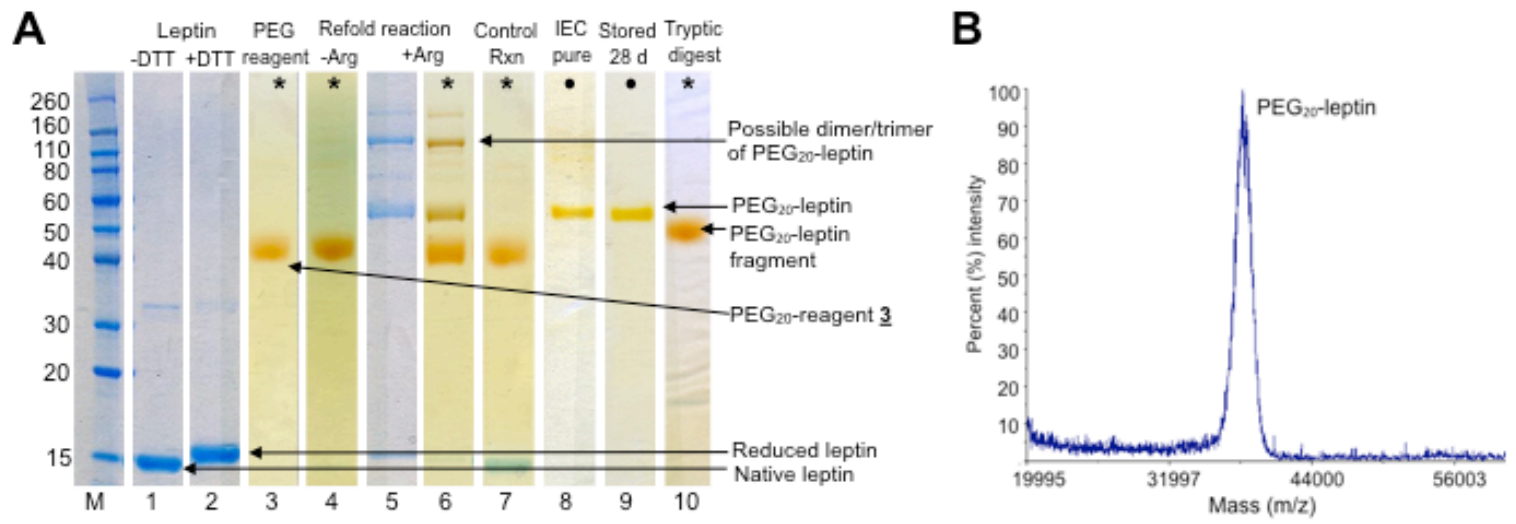

C

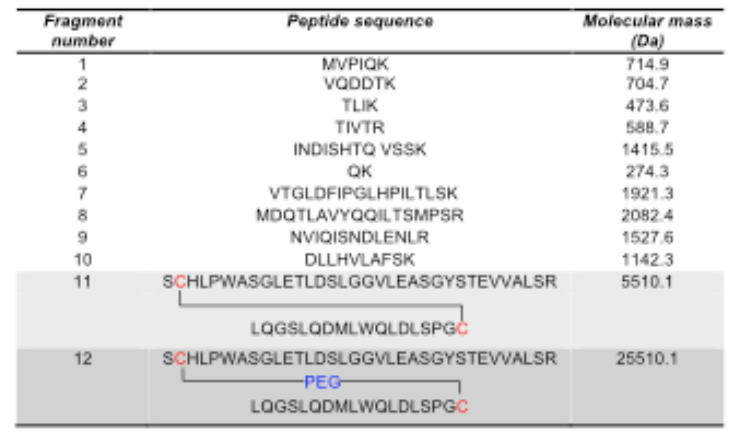

D

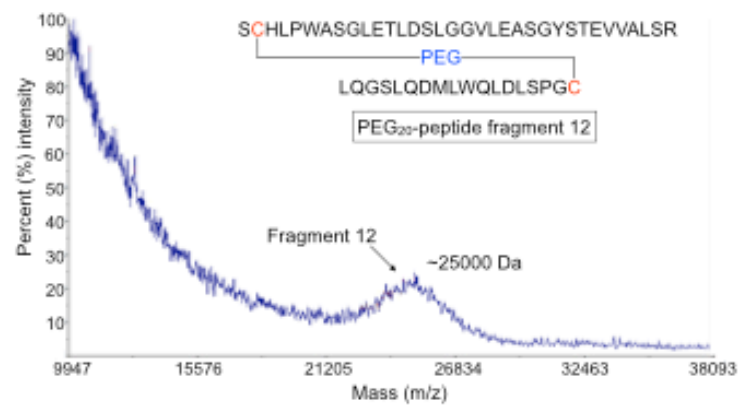


Figure 4

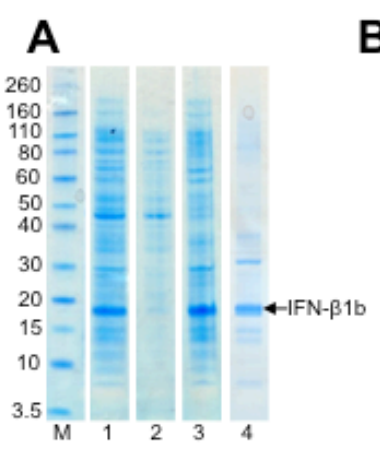

B IFN-B1b PEG Refold Cys-cap Western IEC Stored Tryptic
IBs reagent reaction control IBs Refold pure 2Bd digest

C
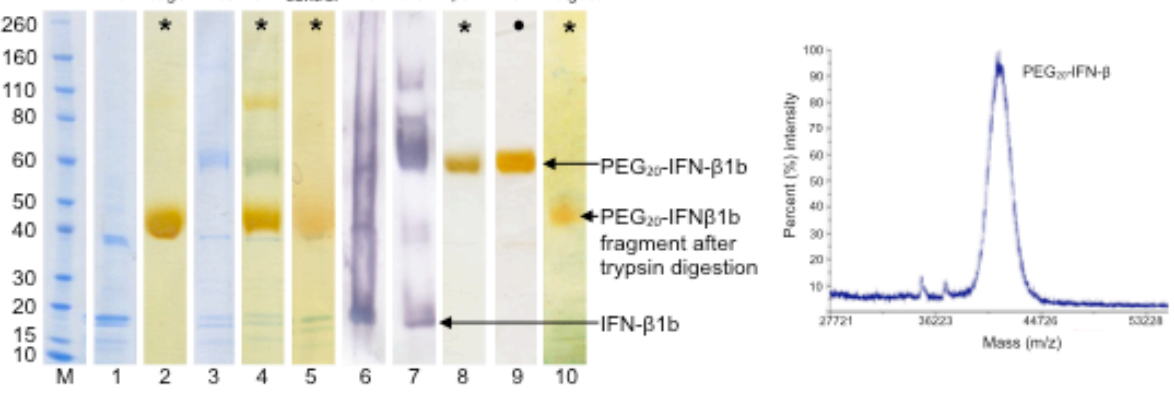

D

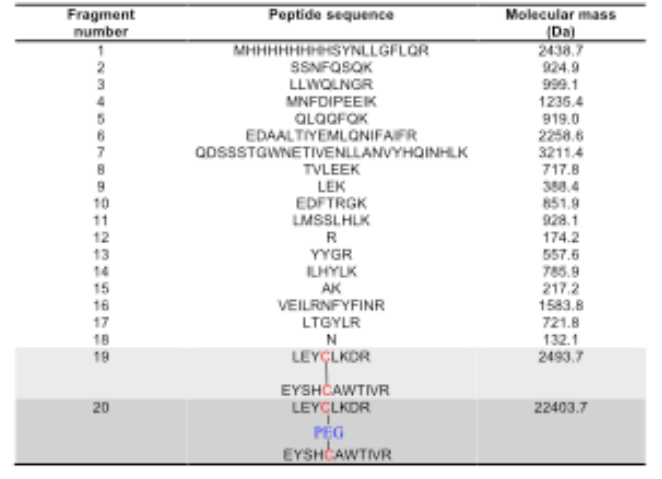

E

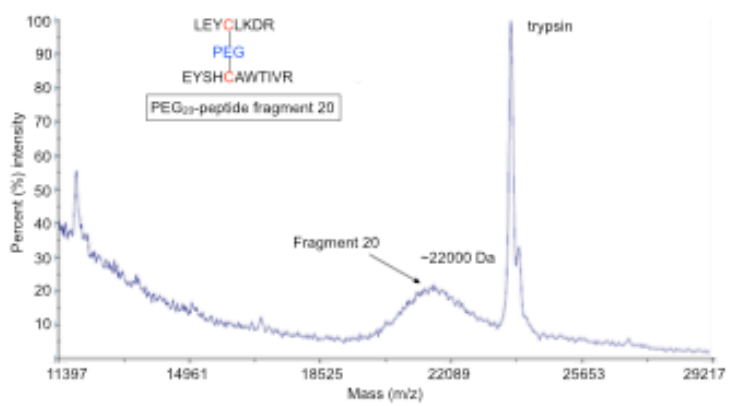


Figure 5
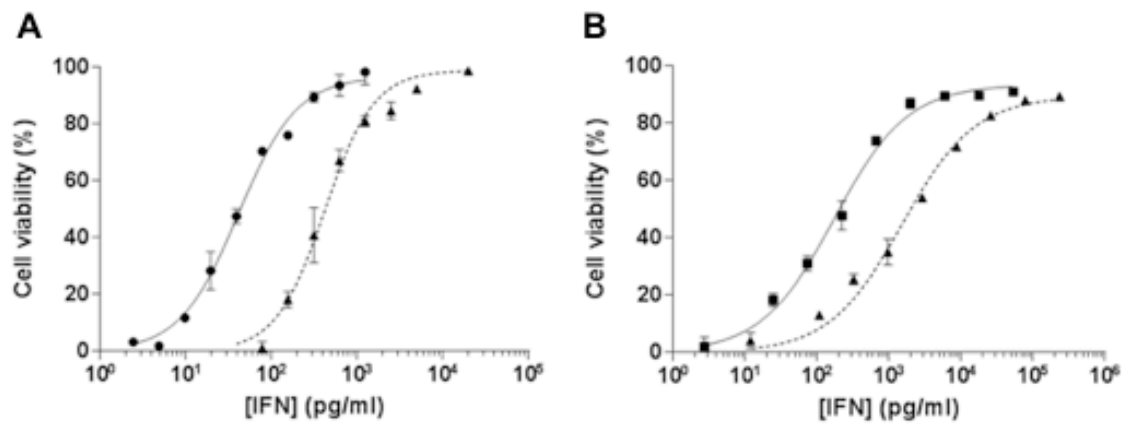


\section{References}

1. Pfister, D. and Morbidelli, M., Process for protein PEGylation. J. Controlled Release, 2014, 180, 134-149.

2. Minten, I. J., Abello, N., Schooneveld-Bergmans, E. F.Van Den Berg, M., Postproduction modification of industrial enzymes. Appl. Microbiol. Biotechnol., 2014, 98, 6215-6231.

3. Smaglo, B. G., Aldeghaither, D.Weiner, L. M., The development of immunoconjugates for targeted cancer therapy. Nat. Rev. Clin. Oncol., 2014, 11, 637648.

4. Deonarain, M. P., Yahioglu, G., Stamati, I.Marklew, J., Emerging formats for nextgeneration antibody drug conjugates. Expert Opin. Drug Discovery, 10, 463-481.

5. Kolate, A., Baradia, D., Patil, S., Vhora, I., et al., PEG - A versatile conjugating ligand for drugs and drug delivery systems. J. Controlled Relesase, 2014, 192, 67-81.

6. Pasut, G. and Veronese, F. M., State of the art in PEGylation: The great versatility achieved after forty years of research. J. Controlled Release, 2012, 161, 461-472.

7. Bailon, P. and Won, C., PEG-modified biopharmaceuticals. Expert Opin. Drug Deliv., 2009, 6, 1-16.

8. Rajan, R. S., Li, T., Aras, M., Sloey, C., et al., Modulation of protein aggregation by polyethylene glycol conjugation: GCSF as a case study. Protein Sci., 2006, 15, 1063 1075.

9. Natalello, A., Ami, D., Collini, M., Dalfonso, L., et al., Biophysical characterisation of Meg-G-CSF: effects of different site-specific mono-Pegylations on protein stability and aggregation. PlosONE, 2012, 7, e42511.

10. Rodriques-Martinez, J., Rivera, I.Griebenow, K., Prevention of benzyl alcoholinduced aggregation of chymotrypsinogen by PEGylation. J. Pharm. Pharmacol, 2011, 63, 800-805.

11. Locke, A. K., Cummins, B. M., Abraham, A. A.Cote, G. L., PEGylation of concanavalin A to improve its stability for an in vivo glucose sensing assay. Anal. Chem., 2014, 86, 9091-9097.

12. Rogue, C., Sheung, A., Rahman, N.Ausar, S. F., Effect of poly(ethylene glycol) conjugation on conformational and colloidal stability of a monoclonal antibody antigen-binding fragment (Fab'). Mol. Pharmaceutics, 2015, 12, 562-575.

13. Warikoo, V., Godawat, R., Kevin Brower, K., Jain, S., et al., Integrated Continuous Production of Recombinant Therapeutic Proteins. Biotechnol. Bioeng., 2012, 109, 3018-3029.

14. Jungbauer, A., Continuous downstream processing of biopharmaceuticals. Trends Biotechnol., 2013, 31, 479-492.

15. Rathore, A. S., Agarwal, H., Sharma, A. K., Pathak, M., et al., Continuous processing for production of biopharmaceuticals. Prep. Biochem. Biotechnol., 45, 836-849. 
16. Konstantinov, K. B. and Cooney, C. L., White Paper on continuous bioprocessing May 20-21, 2014 continuous manufacturing symposium. J. Pharm. Sci., 2015, 104, 813-820.

17. Wellhoefer, M., Sprinzl, W., Hahn, R.Jungbauer, A., Continuous processing of recombinant proteins: Integration of refolding and purification using simulated moving bed size-exclusion chromatography with buffer recycling. J. Chromatogr. A, 2014, 1337, 48-56.

18. Graumann, K. and Premstaller, A., Manufacturing of recombinant therapeutic proteins in microbial systems. Biotechnol. J., 2006, 1, 164-186.

19. Demain, A. L. and Vaishnav, P., Production of recombinant proteins by microbes and higher organisms. Biotechnol. Adv., 2009, 27, 297-306.

20. Huang, C. J., Lin, H.Yang, X., Industrial production of recombinant therapeutics in Escherichia coli and its recent advancements. J. Ind. Microbiol. Biotechnol., 2012, 39, 383-399.

21. Assenberg, R., Wan, P. T., Geisse, S.Mayr, L. M., Advances in recombinant protein expression for use in pharmaceutical research. Curr. Opin. Struct. Biol., 2013, 23, 393-402.

22. Rosano, G. L. and Ceccarelli, E. A., Recombinant protein expression in Escherichia coli: advances and challenges. Front. Microbiol., 2014, 5, Article 172.

23. Spadiut, O., Capone, S., Krainer, F., Glieder, A., et al., Microbials for the production of monoclonal antibodies and antibody fragments. Trends Biotechnol., 2014, 32, 5460.

24. Chen, R., Bacterial expression systems for recombinant protein production: E. coli and beyond. Biotechnol. Adv., 2012, 30, 1102-1107.

25. Villaverde, A. and Carrio, M. M., Protein aggregation in recombinant bacteria: biological role of inclusion bodies. Biotechnol. Lett., 2003, 25, 1385-1395.

26. Cubarsí, R., Carrió, M. M.Villaverde, A., In situ proteolytic digestion of inclusion body polypeptides occurs as a cascade process. Biochem. Biophys. Res. Commun., 2001, 282, 436-441.

27. Singh, S. M. and Panda, A. K., Solubilization and Refolding of Bacterial Inclusion Body Proteins. J. Biosci. Bioeng., 2005, 99, 303-310.

28. Singh, A., Upadhyay, V., Upadhyay, A. K., Singh, S. M., et al., Protein recovery from inclusion bodies of Escherichia coli using mild solubilization process. Microb. Cell Fact., 2015, 14, Article number 14.

29. Cleland, J. L., Builder, S. E., Swartz, J. R., Winkler, M., et al., Polyethylene glycol enhanced protein refolding. Bio/Technology, 1992, 10, 1013-1019.

30. Cleland, J. L., Hedgepeth, C.Wang, D. I., Polyethylene glycol enhanced refolding of bovine carbonic anhydrase B. Reaction stoichiometry and refolding model. J. Biol. Chem. , 1992, 267, 13327-13334.

31. Wang, F., Liu, Y., Li, L., Ma, G., et al., On-column refolding of consensus interferon at high concentration with guanidine-hydrochloride and polyethylene glycol gradients. J. Chromatogr. A, 2006, 1115, 72-80. 
32. Rahimpour, F., Mamo, G., Feyzi, F., Maghsoudi, S., et al., Optimizing refolding and recovery of active recombinant Bacillus halodurans xylanase in polymer-salt aqueous two-phase system using surface response analysis. J. Chromatogr. A, 2007, 1141, 3240.

33. Shaunak, S., Godwin, A., Choi, J. W., Balan, S., et al., Site-specific PEGylation of native disulfide bonds in therapeutic proteins. Nat. Chem. Bio., 2006, 312-313.

34. Balan, S., Choi , J. W., Godwin, A., Teo, I., et al., Site-specific PEGylation of protein disulfide bonds using a three-carbon bridge. Bioconjugate Chem., 2007, 18, 61-76.

35. Brocchini, S., Godwin, A., Balan, S., Choi, J. W., et al., Disulfide bridge based PEGylation of proteins. Adv. Drug Del. Rev., 2008, 3-12.

36. Mather, B. D., Visanathan, K., Miller, K. M.Long, T. E., Michael addition reactions in macromolecular design for emerging technologies. Prog. Polym. Sci., 2006, 31, 487531.

37. Creighton, T. E., Protein folding. Biochem. J., 1990, 270, 10-16.

38. Bulaj, G., Formation of disulfide bonds in proteins and peptides. Biotechnol. Adv., 2005, 23, 87-92.

39. Wedemeyer, W. J., Welker, E., Narayan, M.Scheraga, H. A., Disulfide bonds and protein folding. Biochemistry, 2000, 39, 4207-4216.

40. Mucke, M. and Schmid, F. X., Folding mechanism of ribonuclease T1 in the absence of the disulfide bonds'. Biochemistry, 1994, 33, 14608-14619.

41. Mamathambika, B. S. and Bardwell, J. C., Disulfide-Linked Protein Folding Pathways. Annu. Rev. Cell Dev. Biol., 2008, 24, 211-235.

42. Qin, M., Wang, W.Thirumalai, D., Protein folding guides disulfide bond formation. Proc. Natl. Acad. Sci. U. S. A., 2015, 112, 11241-11246.

43. Wei, J. and Fasman, G. D., A poly(ethylene glycol) water-soluble conjugate of porin: refolding to the native state. Biochemistry, 1995, 34, 6408-6415.

44. Veronese, F. M., Mero, A., Caboi, F., Sergi, M., et al., Site-specific Pegylation of GCSF by reversible denaturation. Bioconjugate Chem., 2007, 18, 1824-1830.

45. Kim, M. Y., Kwon, J. S., Kim, H. J.Lee, E. K., In vitro refolding of PEGylated lipase. J. Biotechnol., 2007, 131, 177-179.

46. Kumagai, I., Asano, R., Nakanishi, T., Hashikami, K., et al., Integration of PEGylation and refolding for renaturation of recombinant proteins from insoluble aggregates produced in bacteria-Application to a single-chain Fv fragment. J. Biosci. Bioeng., 2010, 109, 447-452.

47. Gao, M., Tong, Y., Gao, X.Yao, W., PEGylation-aided refolding of globular adiponectin. World J. Microbiol. Biotechnol., 2013, 29, 1525-1530.

48. Niu, J., Zhu, Y., Song, L., Xie, Y., et al., One-Step production of bioactive proteins through simultaneous PEGylation and refolding. Bioconjugate Chem., 2014, 25, 63 71. 
49. Runkel, L., Meier, W., Pepinsky, R. B., Karpusas, M., et al., Structural and functional differences between glycosylated and non-glycosylated forms of human interferonbeta (IFN-beta). Pharm. Res., 1998, 15, 641-649.

50. Van Beers, M. M. C., Jiskoot, W.Schellekens, H., On the role of aggregates in the immunogenicity of recombinant human interferon beta in patients with multiple sclerosis. J. Interferon Cytokine Res., 2010, 30, 767-775.

51. Lipianien, T., Peltoniemi, M., Sarkhel, S., Yrjonen, T., et al., Formulation and stability of cytokine therapeutics. J. Pharm. Sci., 2015, 104, 307-326.

52. Zhuravko, A. S., Kononova, N. V.Bobruskin, A. I., Features of the solubilisation of interferon beta-1B from inclusion bodies. Russ. J. Bioorg. Chem., 2015, 41, 357-363.

53. Hegen, H., Auer, M.Deisenhammer, F., Pharmacokinetic considerations in the treatment of multiple sclerosis with interferon-b. Expert Opin. Drug Metab. Toxicol., 2015, 11, 1803-1819.

54. Hoy, S. M., Peginterferon Beta-1a: A Review of Its Use in Patients with RelapsingRemitting Multiple Sclerosis. CNS Drugs, 2015, 29, 171-179.

55. Hu, X., Miller, L., Richman, S., Hitchman, S., et al., A novel PEGylated interferon beta-1a for multiple sclerosis: safety, pharmacology, and biology. J. Clin. Pharmacol., 2012, 52, 798-808.

56. Greiner-Stoeffele, T., Grunow, M.Hahn, U., A general ribonuclease assay using methylene blue. Anal. Biochem., 1996, 240, 24-28.

57. Rifkin, R. A., Maggio, E. T., Dike, S., Kerr, D. A., et al., n-Dodecyl- $\beta$-D-maltoside inhibits aggregation of human interferon- $\beta-1 b$ and reduces its immunogenicity. $J$. Neuroimmune Pharmacol., 2011, 6, 158-162.

58. Abkevich, V. I. and Shakhnovich, E. I., What can Disulfide Bonds Tell Us about Protein Energetics, Function and Folding: Simulations and Bioninformatics Analysis. J. Mol. Biol., 2000, 300, 975-985.

59. Thornton, J. M., Disulphide bridges in globular proteins. J. Mol. Biol., 1981, 151, 261287.

60. Khalili, H., Godwin, A., Choi, J., Lever, R., et al., Comparative binding of disulfidebridged PEG-Fabs. Bioconjugate Chem., 2012, 23, 2262-2277.

61. Khalili, H., Khaw, P., Lever, R., Godwin, A., et al., Fab-PEG-Fab as a potential antibody mimetic. Bioconjugate Chem, 2013, DOI 10.1021/bc400246z.

62. Badescu, G., Bryant, P., Bird, M., Henseleit, K., et al., Bridging disulfides for stable and defined antibody drug conjugates. Bioconjugate Chem., 2014, 25, 1124-1136.

63. Lewis, A., Tang, Y., Brocchini, S., Choi, J.-W., et al., Poly(2-methacryloyloxyethyl phosphorylcholine) for Protein Conjugation. Bioconjugate Chem., 2008, 19, 21442155 .

64. Kubetzko, S., Sarkar, C. A.Plückthun, A., Protein PEGylation decreases observed target association rates via a dual blocking mechanism. Mol. Pharmacol., 2005, 68, $1439-1454$. 